\section{PROSPECTS OF MODERN} CASTING METHODS FOR CASES WITH COMPLEX INTERNAL CAVITY

TANYANA NIKOLAEVNA IVANOVA ${ }^{1}$, ZUZANA SAGOVA ${ }^{2}$, ALEKSANDR IVANOVICH KORSHUNOV ${ }^{1}$

${ }^{1}$ Federal State Budgetary Institution of Science, Udmurt Federal Research Center of the Ural Branch of the Russian Academy of Sciences, Institute of Mechanics, Izhevsk, Russia

2Department of Automation and Production Systems, University of Zilina, Faculty of Mechanical Engineering, Zilina,

Slovakia

DOI: 10.17973/MMSJ.2020_10_2020060

tatnic2013@yandex.ru

Several methods of production of castings have been studied via the example of a case part, an axial piston pump back-end cover, namely. These methods include sand mold casting, casting into molds made of cold-hardening mixtures, permanent mold casting, lost-wax casting, lost-foam casting. We have considered only those casting methods, which ensure obtaining of internal cavities with curved axes without the use of coreboxes, inserts or any mechanic interference. The complex design and technological features of the cover made of gray cast iron show the advantages and dis-advantages of each of the casting methods. We have built 3D-models taking into account allowances, laps, roughness and accuracy of castings for each of the studied methods, i.e. sand mold casting, casting into molds made of cold hardening mixtures, permanent mold casting, lost-wax casting, lost foam casting [Baranov 2017, Domanski 2017, Elbakian 2018]. The examined casting methods have been compared in terms of the technological pro-cesses required, time needed to obtain a casting, staff qualification. The calculation of material utilization ratio has been carried out. As a result of research conducted, it was discovered that the optimum method of production of a casting with complex internal configuration is casting into molds made of cold-hardening mixtures. The research analysis has shown that this method requires the less time to preparation for casting production, than other methods. What is more, surface roughness and geometric specifications accuracy are also better than the ones, provided by other casting methods.

KEYWORDS

modelling, material utilization ratio, sand mold casting, casting into molds made of cold-hardening mixtures, permanent mold casting, lost-wax casting, lost-foam casting

\section{INTRODUCTION}

The use of new technologies changes metalworking at any stage of production: from the introduction of innovative methods for obtaining blanks and the design of products of the most complex shape, to the technological adjustment of production processes for the manufacture of parts of a unique shape [Sapietová 2018, Kuric 2017].

Having studied an axial-piston pump back-end cover, made of grey cast iron SCH15 GOST 1412 - 85 (C415 - ГOCT 1412 85) [GOST 1996, GOST 2012] as a blank of complex shape, it was established that the casting has a complex configuration due to the holes with curved axes, which share one plane of inlet and outlet to the part, while there is only one inlet hole in the part (Fig. 1).

The part has six through-holes with diameter of $13 \mathrm{~mm}$ each. These holes have the roughness equal to $\mathrm{Ra}=12.5$ microns, while average roughness of the part is $\mathrm{Ra}=25$ microns. The holes are processed by drilling, countersinking and hole-reaming. The case itself has oval-rectangular shape, the profile is $40 \mathrm{~mm}$ high and $113 \mathrm{~mm}$ wide. The front side has 4 bevels of round shape. Through-holes are milled to create the sockets for flatheads of fastening elements. On the back side of the part there are three hollow holes with diameter of $8 \mathrm{~mm}$. During the techno-logical process the holes with curved axes are processed by electrochemical method. After this processing the holes are getting their finished profile.

\section{MATERIALS AND METHODS}

To select the optimum variant of production of the blank, the next indices have been analyzed: material, shape of the part, mass, technical requirements and production volume [Baranov 2017, Domanski 2017, Elbakian 2018, GOST 1996, GOST 2012, Kosilova 2003, Krawiec 2017, Krenicky 2008, Krenicky 2012, Kuric 2017, Macko 2018]. It was necessary to select those production methods of castings, which ensure obtaining of internal cavities with curved axes without the use of coreboxes, inserts or any mechanic interference. So, the next casting methods have been taken into account: sand mold casting, casting into molds made of cold-hardening mixtures, permanent mold casting, lost-wax casting, lost-foam casting.

Sand mold casting provides production of the blanks with mass up to 10 tons and surface roughness $\mathrm{Rz}=200$ microns. It is impossible to cast a part with cavities with curved axes, because casting insert cannot be removed [Krenicky 2012]. In addition, assignment of high value of allowances and laps of surfaces of the casting would be required.

The feature of molds made of cold-hardening mixtures is that they are hardened and strengthened under atmospheric temperature. Cold-hardening mixtures consist of quartz sand, resin, a catalyst of resin hardening and regulators of hardening rate. This casting method is significant because it ensures accurate and smooth casting surfaces, which makes mechanical processing unnecessary [Kosilova 2003, Krawiec 2017]. In case of casting in molds made of cold-hardening mixtures, production of the blanks with mass up to $500 \mathrm{~kg}$ and surface roughness $\mathrm{Ra}=25$ microns is provided. This casting method ensures production of blanks with cavities with curved axes without the use of any inserts. What is more, full absence of laps is possible, only allowances for mechanical processing are required.

In case of permanent mold casting, reusable molds of metal are used. The complex part cannot be casted with its curved axis holes by means of this method, as in this case it is impossible to remove the resulting casting from the mold. If permanent mold casting is selected for production of axialpiston pump back-end cover, it entails the casting of the blank without its curved axis holes. In this case, there is another problem, which complicates technological process: how to create these holes after the blank have been casted?

Lost-wax casting implies formation of a model from lowmelting point materials in a press mold, which is then covered by flame resisting composition. After chemical hardening, this composition creates a solid layer around the model. Then the model is melted, shell mold is ignited. After this, it is sprinkled with sand or grit to prevent from destruction and melted mass is applied. Shell molds are produced by repeated sequence of 
immersion of the model in the suspension and sprinkling with grain material. The model can have the cavities of complex shape and their casting does not require the setting of inserts. After the casting process has been done, the casting is exposed to vibration or mechanical interference in order to remove it from the model [Krenicky 2008]. Under the influence of these operations the model is destroyed, releasing the casting.

\section{RESULTS AND DISCUSSION}

The models for lost-foam casting are made of light-mass foam materials, which are not removed from mold after forming. The foam materials remain in casting mold and during
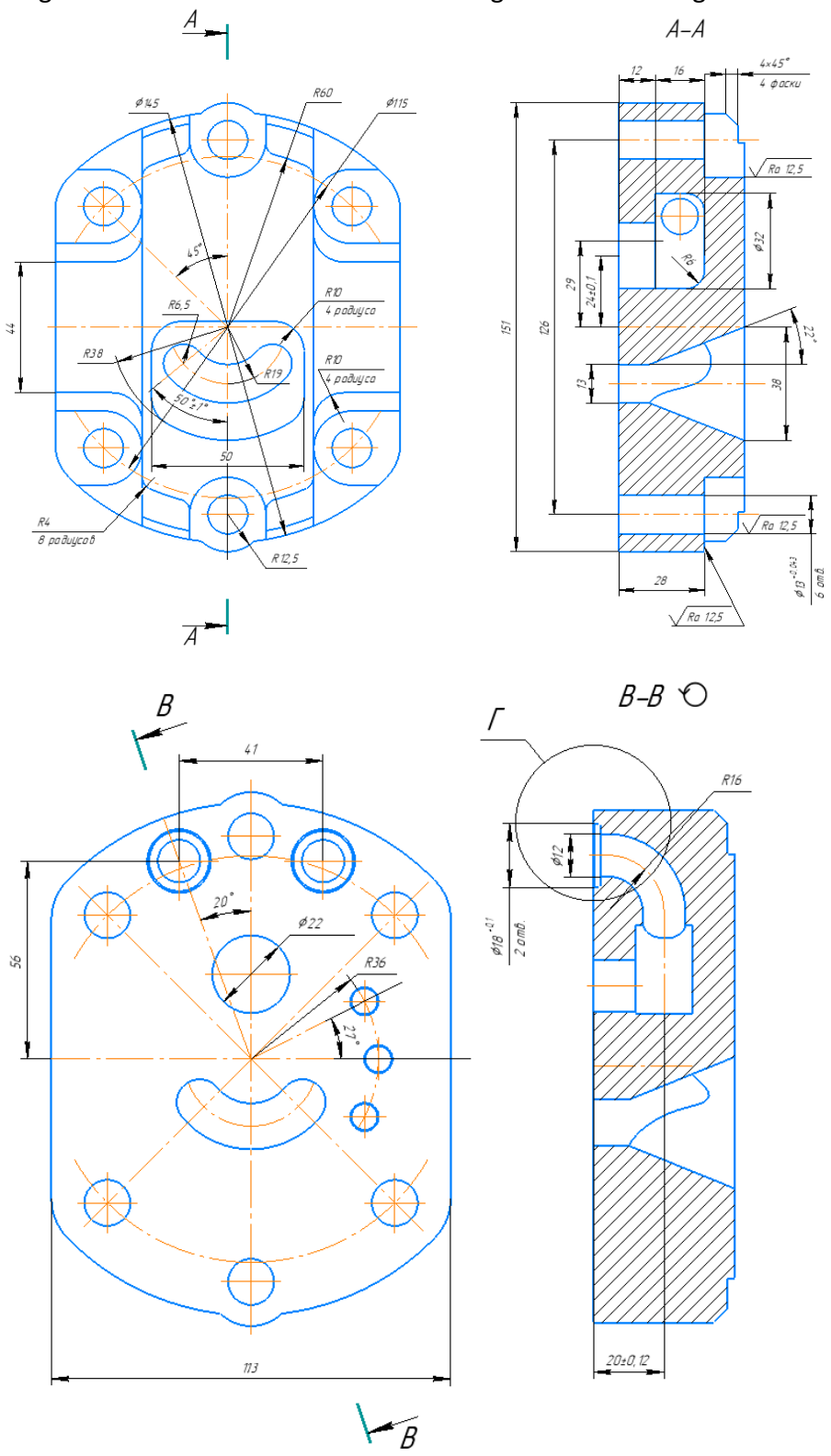

metal pouring they gasify due to heat of melted mass, poured into the mold. An increase in the accuracy of castings is reached due to the absence of casting slopes, which reduces the allowance for mechanical processing. In addition, the absence of operations for removal of the model from mold has made the mold a solid piece and, consequently, it has increased the accuracy of castings due to prevention from shifts and skews of separate parts of the mold relatively to each other [Macko 2018, Saga 2020]. The possibility to form internal configuration of the casting fully in a model without any inserts simplifies forming process, increases casting accuracy and enhances the range of complex shape castings.
Figure 1. The part and its model in SW SolidWorks

Due to a difference in values of allowances and laps as well as the absence of the curved axis holes, the castings made of the same material have different material utilization ratios for each production method. Figures 2-5 demonstrate the casting models with allowances and laps for the production methods, mentioned above. Table 1 lists material utilization ratios, given the part mass is $3.08 \mathrm{~kg}$.

In case of casting into molds made of cold-hardening mixtures, the mass of the blank is $3.7 \mathrm{~kg}$. What is more, the profile of the curved axis holes is already formed.

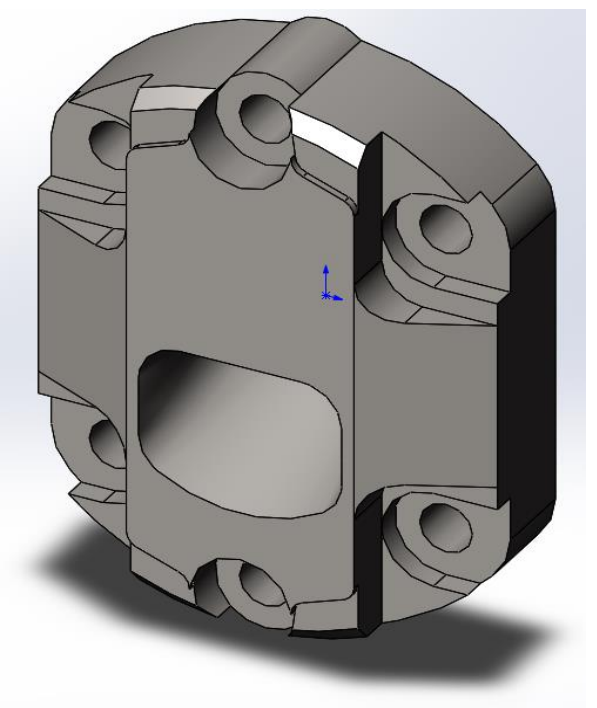

B-B

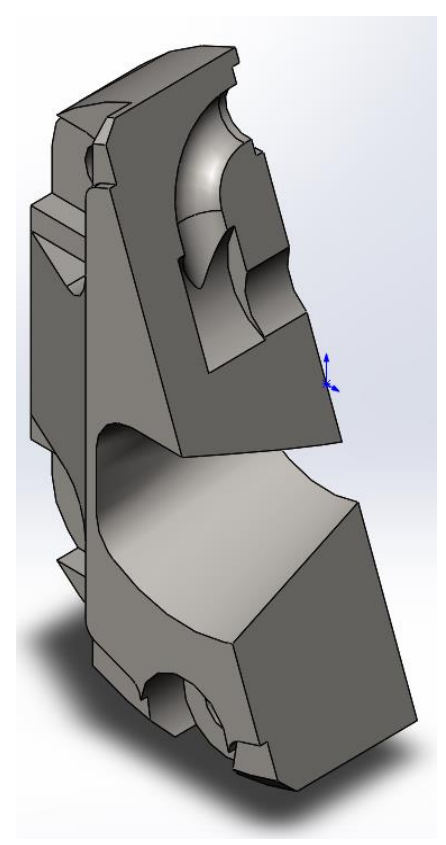

Table 1. Comparison of material utilization ratio

\begin{tabular}{|c|c|}
\hline Casting method & Material utilization ratio \\
\hline Sand mold casting & 0.77 \\
\hline $\begin{array}{c}\text { Casting into molds made of } \\
\text { cold-hardening mixtures }\end{array}$ & 0.83 \\
\hline Permanent mold casting & 0.78 \\
\hline Lost-wax casting & 0.82 \\
\hline Lost-foam casting & 0.81 \\
\hline
\end{tabular}



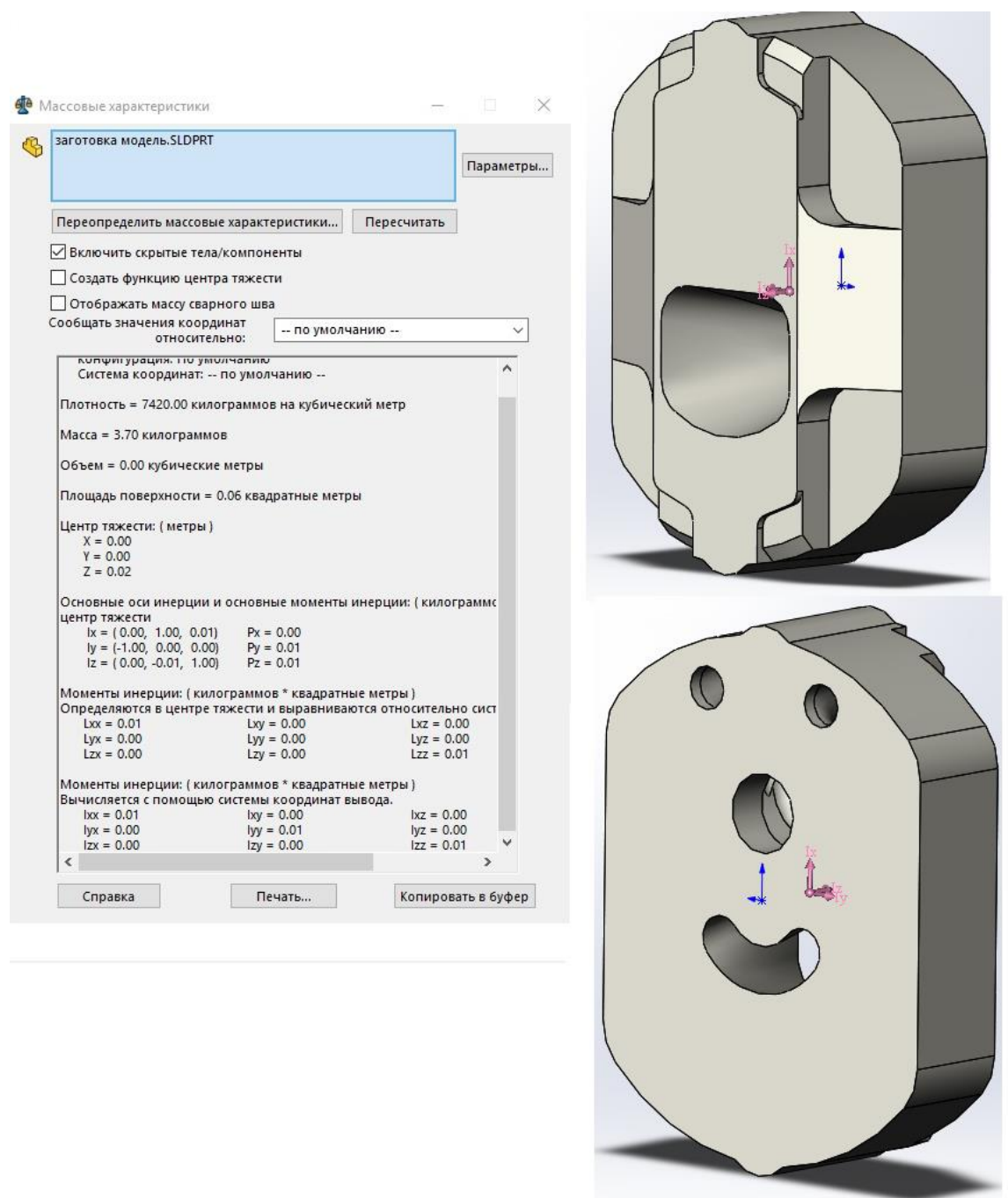

Figure 2. The model of a blank, produced by casting into molds made of cold-hardening mixtures (CHM)

Legend: Массовые характеристики - mass properties

SLDPRT - casting model

Параметры - options

Пересчитать массовые характеристики - recalculate mass properties

Пересчитать - recalculate

Включить скрытые теда/компоненты - include hidden bodies/components

Создать функцию центра тяжести - create center of mass feature

Отображать массу сварного шва - show weld bead mass

Сообщать значения координат относительно --по умолчанию-- - report coordinate values relative to --default--

Конфигурация: по умолчанию - Configuration: default

Система координат: по умолчанию - Coordinate system: default

Плотность $=7420$ килограммов на кубический метр - density $=7420 \mathrm{~kg}$ per cubic meter

Масса $=3.7$ килограммов - mass $=3.7 \mathrm{~kg}$

Объем $=00$ кубические метры - volume $=00$ cubic meters

Площадь поверхности $=0.06$ кв.метры - surface area $=0.06$ square meters

Центр тяжести: (метры) - center of mass: (meters)

Основные оси инерции и основные моменты инерции: (килограммов*кв.метры) центр тяжести - principal ax-es of inertia and principal moments of inertia: (kilograms*square inches) taken at the center of mass

Моменты инерции: (килограммов*кв.метры) определяются в центре тяжести и выравниваются относительно системы координат вывода moments of inertia: (kilograms*square inches) taken at the center of mass and aligned with the output coordinate system

Моменты инерции: (килограммов*кв.метры) вычисляется с помощью системы координат вывода - Moments of inertia: (kilograms*square inches) taken at the output coordinate system

Справка - help

Печать - print

Копировать в буфер - copy to clipboard 

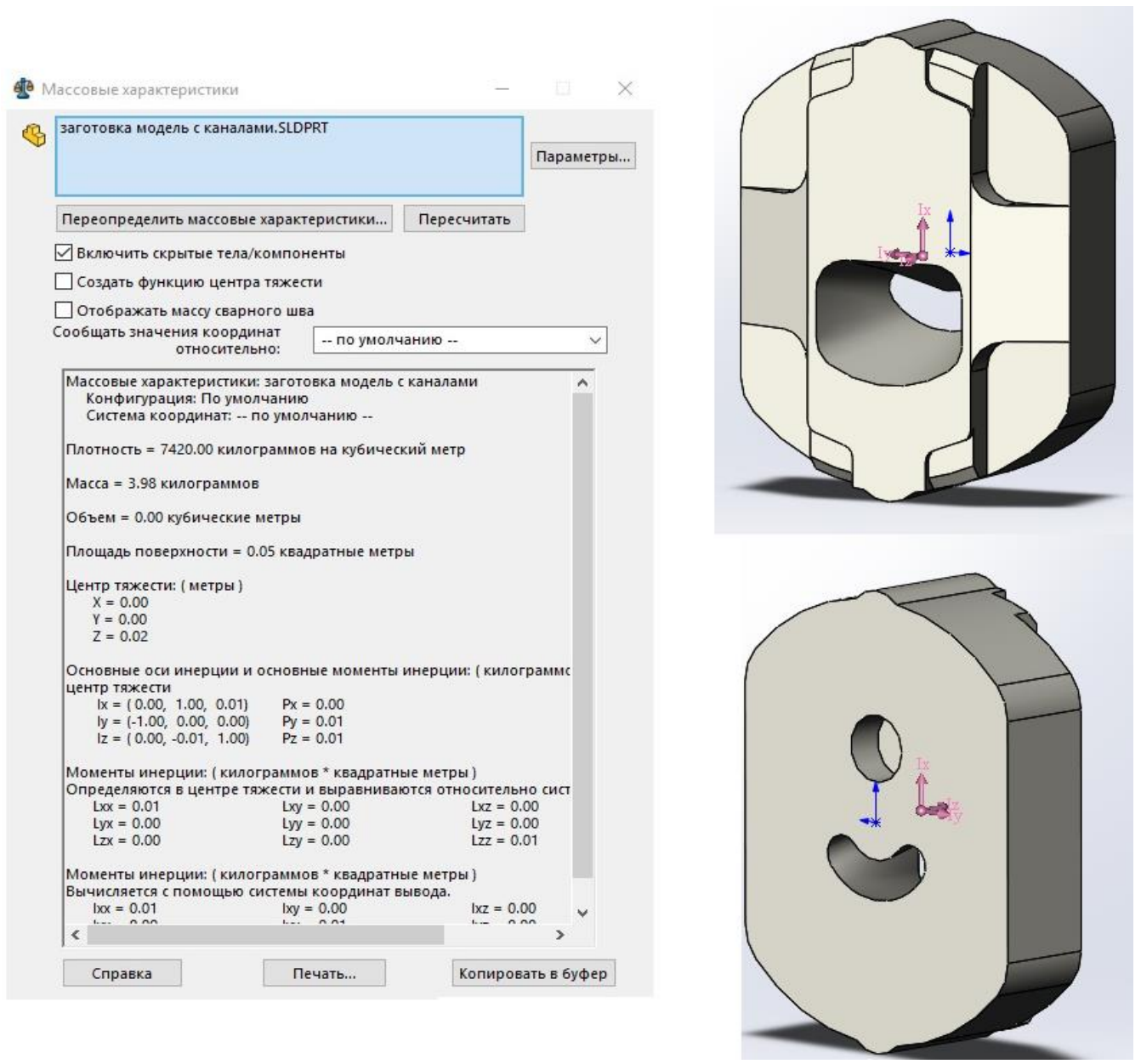

Figure 3. The model of the blank, produced by sand mold casting

Sand mold casting requires the absence of the holes with curved axes and the mass of the blank is $3.98 \mathrm{~kg}$. As for permanent mold casting of the same blank, it's mass reaches $3.94 \mathrm{~kg}$.
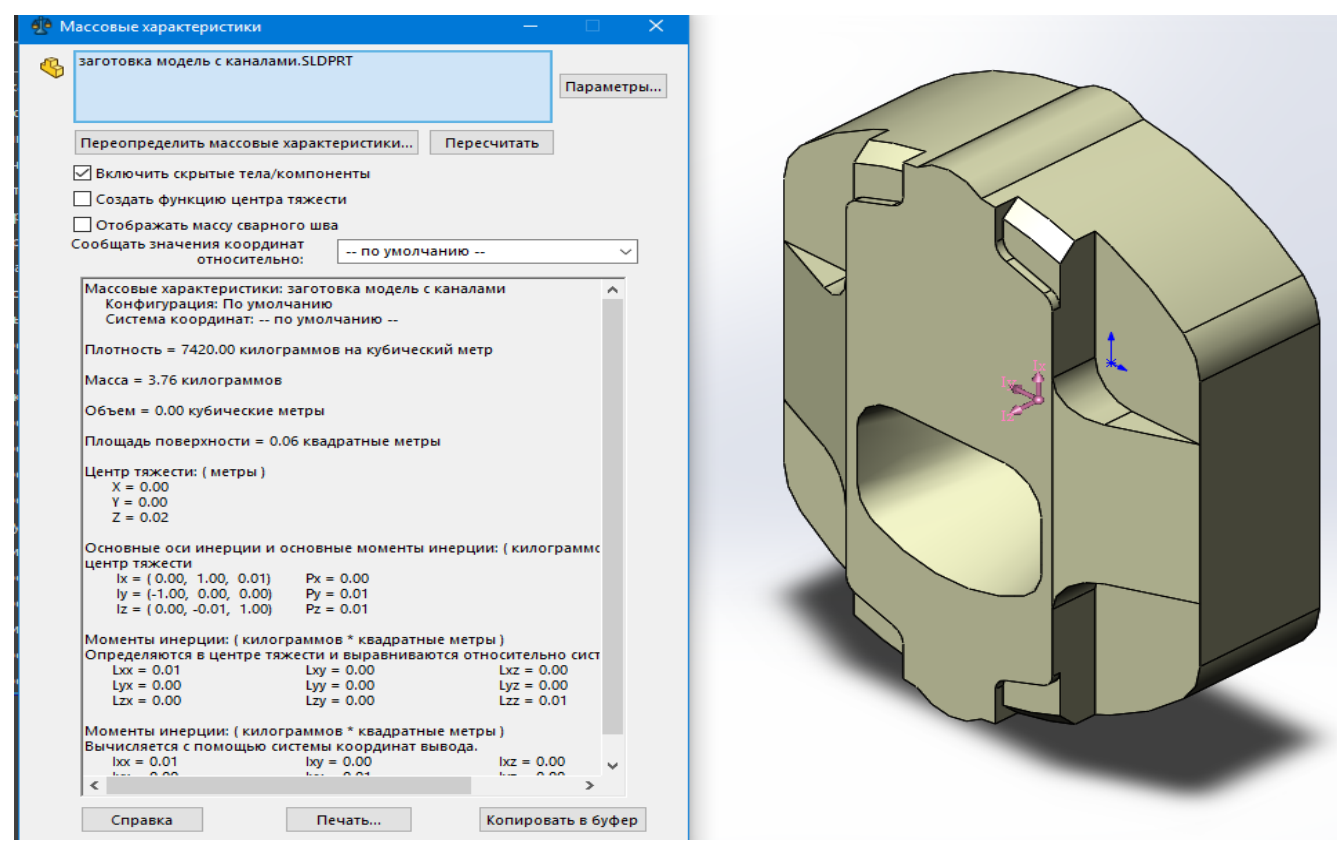

Figure 4. Mass characteristics for lost-foam casting 

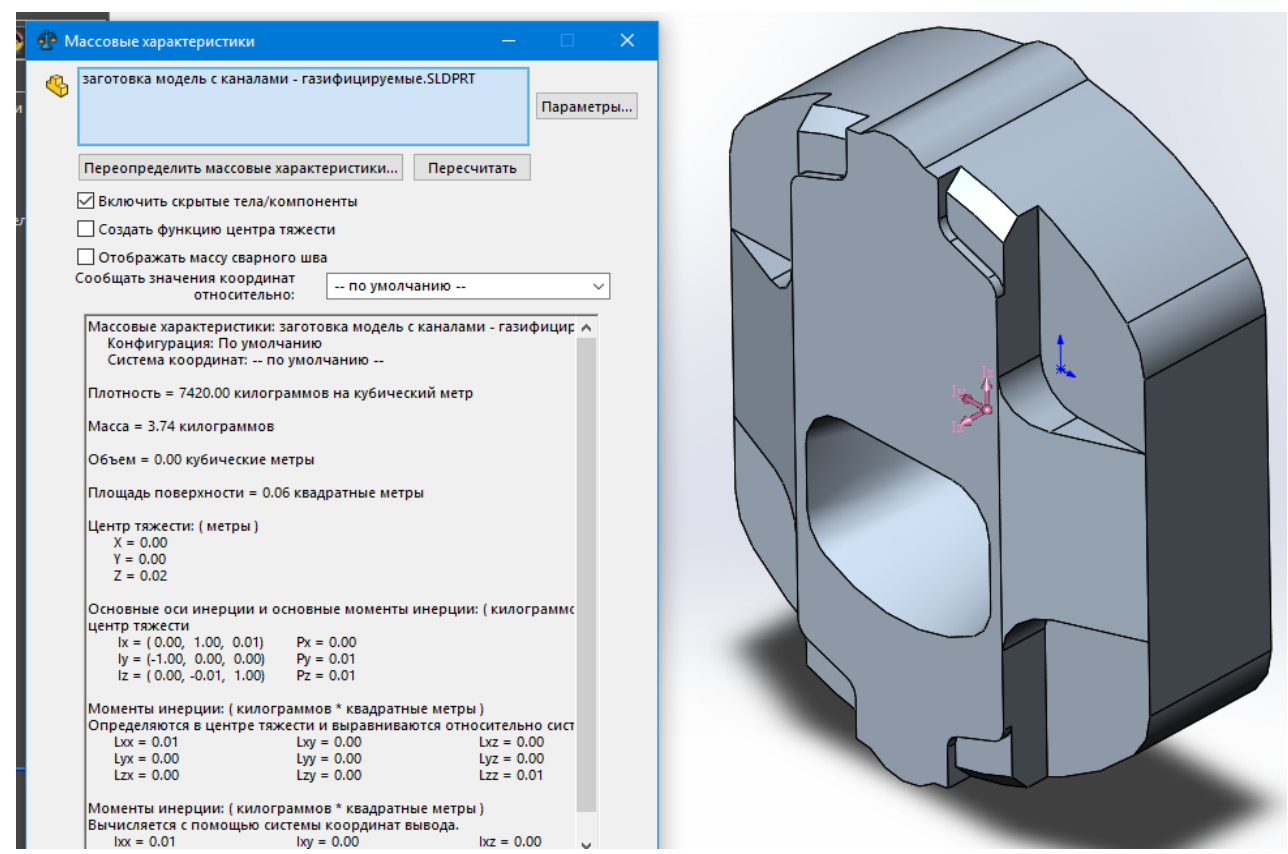

Figure 5. Mass characteristics for lost-wax casting

Comparative data of the parameters of the castings are given in Tables $2-4$.

Table 2. Accuracy and roughness of the castings

\begin{tabular}{|c|c|c|}
\hline $\begin{array}{c}\text { Casting } \\
\text { method }\end{array}$ & $\begin{array}{c}\text { Accuracy of castings, } \\
\text { quality degree }\end{array}$ & $\begin{array}{c}\text { Surface } \\
\text { roughness, } \mu \mathrm{m}\end{array}$ \\
\hline $\begin{array}{c}\text { Lost-wax } \\
\text { casting }\end{array}$ & $11-14$ & $\mathrm{Rz}=(10,40)$ \\
\hline $\begin{array}{c}\text { Lost-foam } \\
\text { casting }\end{array}$ & $11-12$ & $\mathrm{Rz}=(10,40)$ \\
\hline $\begin{array}{c}\text { Casting into } \\
\text { CHM molds }\end{array}$ & $10-12$ & $\mathrm{Ra}=(5,25)$ \\
\hline
\end{tabular}

Table 3. Comparison of technical processes and time to produce the casting

\begin{tabular}{|c|c|c|c|}
\hline Index & Lost-wax casting & $\begin{array}{l}\text { Lost-foam } \\
\text { casting }\end{array}$ & $\begin{array}{l}\text { Casting into } \\
\text { CHM molds }\end{array}$ \\
\hline $\begin{array}{l}\text { Accesso- } \\
\text { ries }\end{array}$ & $\begin{array}{l}\text { With use of mould } \\
\text { press }\end{array}$ & $\begin{array}{l}\text { With use of } \\
\text { mould press }\end{array}$ & $\begin{array}{l}\text { With use of } \\
\text { classic } \\
\text { model } \\
\text { accessory }\end{array}$ \\
\hline $\begin{array}{l}\text { Technolo- } \\
\text { gical } \\
\text { process }\end{array}$ & $\begin{array}{l}\text { 1) Creation of a } \\
\text { model } \\
\text { 2) Creation of a } \\
\text { mold } \\
\text { 3) Melting of the } \\
\text { model and mold } \\
\text { drying } \\
\text { 4) Mold ignition } \\
\text { 5) Control of mold } \\
\text { 6) Melting and } \\
\text { pouring of metal }\end{array}$ & $\begin{array}{l}\text { 1) Creation of } \\
\text { a model } \\
\text { 2) Creation of } \\
\text { a mold and its } \\
\text { assembling } \\
\text { 3) Mold drying } \\
\text { 4) Control of } \\
\text { mold } \\
\text { 5) Melting and } \\
\text { pouring of } \\
\text { metal }\end{array}$ & 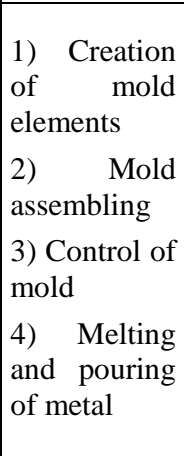 \\
\hline $\begin{array}{l}\text { Average } \\
\text { time of } \\
\text { manufac- } \\
\text { ture }\end{array}$ & 2-3 months & 1 month & 1.5 month \\
\hline $\begin{array}{l}\text { Qualifica- } \\
\text { tion }\end{array}$ & $\begin{array}{l}\text { Requires educated } \\
\text { qualified staff }\end{array}$ & $\begin{array}{l}\text { Does not } \\
\text { require high } \\
\text { qualification }\end{array}$ & \begin{tabular}{|l} 
Requires \\
educated \\
qualified \\
staff
\end{tabular} \\
\hline
\end{tabular}

Table 4. Allowance for mechanical treatment
\begin{tabular}{|c|c|c|c|}
\hline \multirow{2}{*}{ Casting method } & \multicolumn{3}{|c|}{$\begin{array}{c}\text { Allowance for mechanical } \\
\text { treatment of surfaces by } \\
\text { means of milling of the } \\
\text { casting, mm (Fig. 6) }\end{array}$} \\
\cline { 2 - 4 } & 40 & 22 & 28 \\
\hline Lost-wax casting & 3.7 & 3.2 & 3.6 \\
\hline Lost-foam casting & 3.9 & 3.4 & 3.6 \\
\hline Casting into CHM molds & 3.7 & 3.2 & 3.5 \\
\hline
\end{tabular}
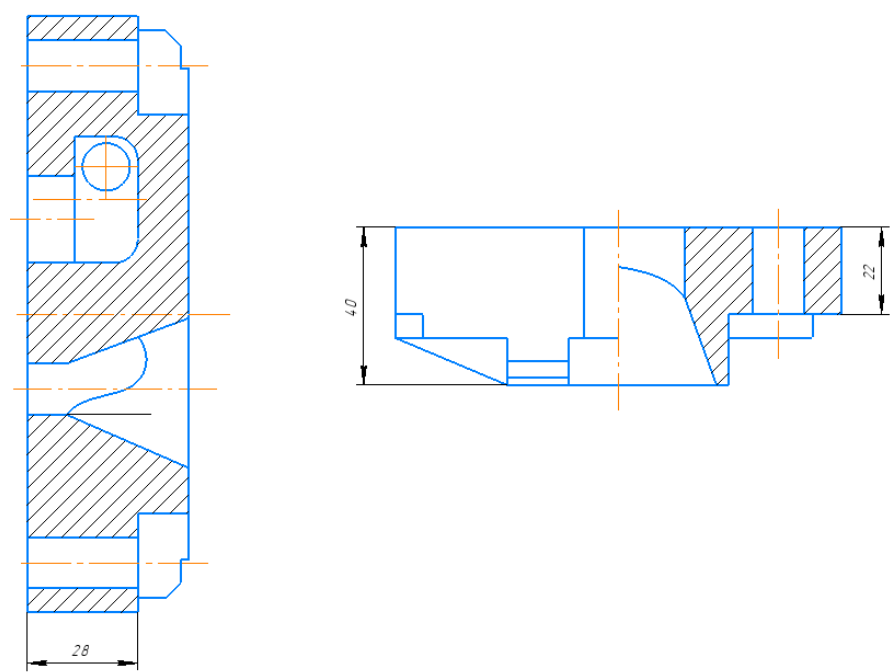

Figure 6. The nominal dimensions of the surfaces to which the allowance is assigned in Table 5

\section{CONCLUSIONS}

As a result of the research conducted, it has been discovered that the optimum method of production of a blank with complex internal configuration is casting into molds made of cold-hardening mixtures. This method requires the shortest time for preparation for casting production in comparison with 
other methods. What is more, surface roughness and geometric specifications accuracy are also better than the ones, provided by other casting methods [Turygin 2018].

- All castings have almost the same dimensional accuracy.

- Lost-foam casting is the only casting method that does not require high qualification of work personnel.

- Casting into molds made of cold-hardening mixtures ensures the best roughness parameters.

- Casting into molds made of cold-hardening mixtures requires the shortest time to prepare the molds for newly produced blanks.

- The best way to provide complex profile of internal configuration is lost-foam casting as it is not necessary to remove a model from a mold.

- Material utilization ratio (RMU) is almost the same; however, it is the highest in case of casting into $\mathrm{CHM}$ molds.

- The highest allowances for mechanical treatment are shown in case of lost-foam casting.

As casting into molds made of cold-hardening mixtures has been selected as the most preferred, the drawing of the casting has been developed (Figs. 7, 8).
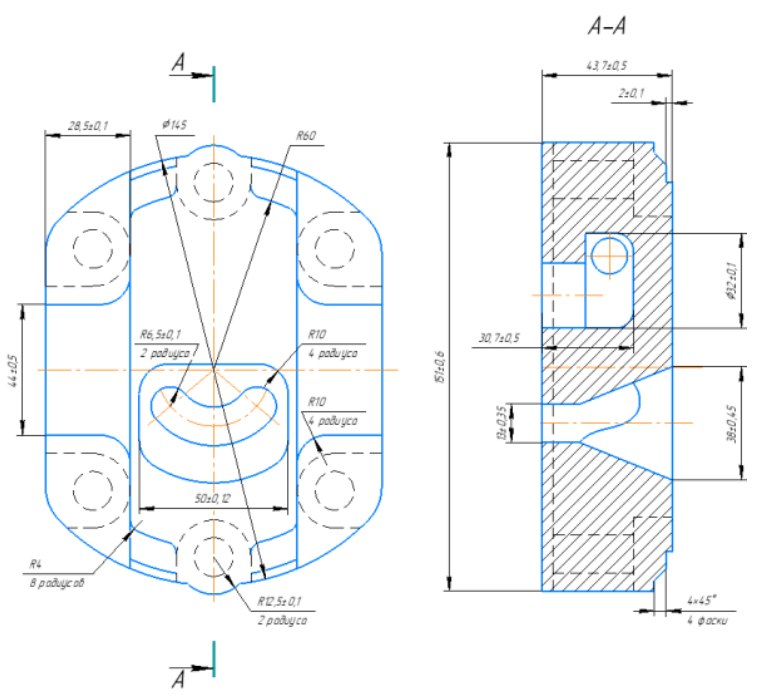

Figure 7. Drawing of the casting, front view, section A - A

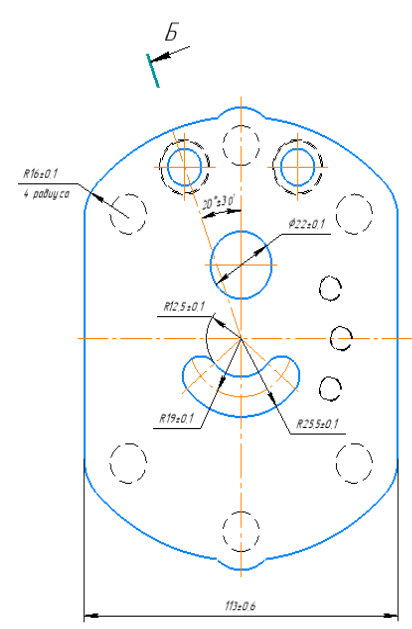

$5-50$

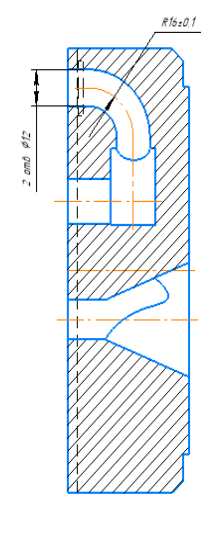

$W_{6}$

Figure 8. Drawing of the casting, back view, section $\bar{B}-\overline{5}$

Thus, the search for a method for castings production, which provides creation of internal cavities of a complex configuration, covered a wide range of indicators of modern production of blanks.

\section{ACKNOWLEDGEMENTS}

The work was financially supported by the Russian Foundation for Basic Research (RFBR), grant No. $18-48-80006 \mathrm{p}$ a. This article was prepared with the support of APVV project - APVV16-0283. Project title: Research and development of multicriteria diagnosis of production machinery and equipment based on the implementation of artificial intelligence methods and research project KEGA No: 001ŽU-4/2020.

\section{REFERENCES}

[Baranov 2017] Baranov, M.N. et al. Constructing and calculating of multistage sucker rod string according to reduced stress. Acta Montanistica Slovaca, 2017, Vol. 22, Issue: 2, pp. $107-115$

[Domanski 2017] Domanski, T. et al. Application of Abaqus software for the modeling of surface progressive hardening. In: 21st Polish-Slovak International Scientific Conference on Machine Modeling and Simulations MMS 2016, Poland. Book Series: Procedia Engineering, 2017, Vol. 177, pp. 64-69.

[Elbakian 2018] Elbakian, A. et al. Automated Separation of Basalt Fiber and Other Earth Resources by the Means of Acoustic Vibrations. Acta Montanistica Slovaca, 2018, Vol. 23, No. 3, pp. 271-281.

[GOST 1996] GOST 26645-85 Metal and alloy castings. Dimensions and mass tolerances and machining allowances (with Change 1). - Introduced 1987-07-01. - M.: USSR State Committee for Standards 1996.

[GOST 2012] GOST 3.1121 - 84. Unified system of technological documentation. General requirements for completeness and arrangement of sets of documents on typical and group technological processes (operations). - Introduced 1986-01 01. - M.: Standardinform, 2012.

[Kosilova 2003] Kosilova, A. et al. Directory of Technology Mechanical Engineer Vol. 2. 6th ed., Rev. and additional. Mechanical Engineering, 2003, 495 p.

[Krawiec 2017] Krawiec, P. Analysis of selected dynamic features of a two-wheeled transmission system. J. Theor. Appl. Mech., 2017, Vol. 55, pp. 461-467.

[Krenicky 2008] Krenicky, T. Methods and means of eliminating sources of vibration for die casting machines. Technological Engineering, 2008, Vol. 5, No. 2, pp. 58-59.

[Krenicky 2012] Krenicky, T. Automated noncontact system for characterization of surface geometry. In: Proc. of Int. Sci. Conf. Automation and control in theory and practice ARTEP 2012. Feb. 22-24, 2012, Stara Lesna, Slovak Republic. Kosice: TUKE, 2012. pp. 38/1-5.

[Kuric 2017] Kuric, I. et al. Development of simulation software for mobile robot path planning within multilayer map system based on metric and topological maps. International Journal of Advanced Robotic Systems, 2017, Vol. 14 Issue 6, pp. 1-14.

[Macko 2018] Macko, M. et al. The use of CAD applications in the design of shredders for polymers. MATEC Web of Conferences, 2018, Vol. 157, Art. No 02027, e-ISSN: 2261-236X.

[Saga 2020] Saga, M. et al. Case study: Performance analysis and development of robotized screwing application with integrated vision sensing system for automotive industry. International Journal of Advanced Robotic Systems, 2020, Vol. 17, Issue 3, pp. 1-23. 
[Sapietová 2018] Sapietová, A. et al. Application of optimization algorithms for robot systems designing. International Journal of Advanced Robotic Systems, 2018, Vol. 15, Issue 1, pp. 1-10.

[Turygin 2018] Turygin, Yu. et al. Reliability determination and diagnostics of a mechatronic system. In Advances in Science and Technology Research Journal, 2018, Vol. 12, Issue 2, pp. 274-290.

\section{CONTACTS:}

Prof. Dr. Tanyana Nikolaevna Ivanova, Dr.Sc.

Tchaikovsky Branch Perm National Research Polytechnic Institute,

Lenin St. 73, Tchaikovsky, 617764, Russia

e-mail: tatnic2013@yandex.ru
Ing. Zuzana Sagova, PhD.

Department of Automation and Production Systems, University of Žilina, Faculty of Mechanical Engineering, Žilina, Slovakia e-mail: Zuzana.Sagova@fstroj.uniza.sk

Prof. Dr. Aleksander Ivanovich Korshunov, Dr.Sc. Federal State Budgetary Institution of Science Udmurt Federal Research Center of the Ural Branch of the Russian Academy of Sciences Institute of Mechanics, T. Baramzinoy Str., 34, Izhevsk, Russia, 426000, Udmurt Republic, Russia

e-mail: kai@udman.ru 